\title{
A Meta-ethnographic Synthesis of Support Services in Distance Learning Programs
}

\author{
Jean Marie Tuquero \\ Commander William C. McCool Elementary/Middle School, \\ Department of Defense Education Activity-Guam District \\ Sumay, Guam, USA
}

Jean.Tuquero@pac.dodea.edu

Executive Summary

This qualitative study utilized a meta-ethnographic approach to synthesize findings of five dissertations that focused on distance learning support services. The history of ethnographical studies stemmed from an anthropological background. Researchers have applied ethnographical approaches to examine and document various phenomena. This meta-ethnographical study explored existing research on distance learning support services in higher education. Each individual researcher of the five dissertations used in this study established validity through coding, crosscoding, and triangulation for their results.

The approach of this meta-ethnographic study consisted of seven phases: (a) phase 1-getting started with a literature review, (b) phase 2-deciding what is relevant to initial interest, (c) phase 3-reading the studies, (d) phase 4-determining how studies are related, (e) phase 5-translating studies into one another, (f) phase 6-synthesis translation, and (g) phase 7-expressing synthesis. Each phase assisted in the identification process of possible relationships, interpretations, multiple perspectives, and analogies from the five dissertations identified for this study. The in-depth scrutiny of each dissertation required multiple readings. Therefore, qualitative data analysis software assisted in the codification of metaphors and aided in maintaining objectivity during the interpretive phase of the meta-ethnographic process.

The iterative nature of reading and investigating dissertations required for meta-ethnographies revealed the relationships evident in distance learning support services relevant to adult learners. The relationships between the dissertations highlighted these four holistic themes with core elements connected to current developments in distance learning support services: (a) web-based design, (b) support services, (c) stakeholder perceptions, and (d) learner attrition. The results of this meta-ethnographical study will assist the future design and framework of support service functions in distance learning.

Keywords. distance education, adult learning theory-andragogy, self-directed, meta-ethnography, qualitative

\section{Introduction}

The exponential developments and advancements in the technology field broadened traditional educational institutions' curriculum to include distance learning programs (Conrad \& Dondaldson, 2004, p. 7; Palloff \& Pratt, 1999, p. 3). Adult learners realized the potential of distance learning programs as options for learning new skills. Distance learning program's online format united adult learners with differing backgrounds, life experiences, and geographical locations through e- 
learning communities. E-learning encompassed the distance learning programs that required information technology (IT), information and communication technologies (ICT), computermediated communication (CMC), virtual learning environment (VLE), and computer conferencing (Fischer \& Baird, 2006; Garrison \& Cleveland-Innes, 2005; Gipps, 2005; Maor, 2003; Marra, Moore, \& Klimczack, 2004; Oliver \& Conole, 2003; Palloff \& Pratt, 1999).

This qualitative study used Noblit and Hare's (1988) meta-ethnographic approach to synthesize findings of five case studies that contained information on online support services and adult learners. The study analyzed the commonalities in current student support areas that surrounded adult learning issues. The analysis consolidated current research with online support services and contributed to the future of online programs. For this analysis, online support services consisted of web-based education design, establishing training needs, and an interconnected system of partners in these distance learning categories: (a) academic services, (b) communications, (c) administrative core, (d) student communities, and (e) personal services (Western Cooperative for Educational Telecommunications, 2002).

Consolidation of the current findings assisted in steering the development of effective and efficient online support services in distance education. The rapid development of e-learning in higher education coincided with the increasing adult learner population. The field of support services in e-learning for adult learners was worthy of further investigation so online universities could identify valuable support service areas that needed adjustment (Floyd \& Casey-Powell, 2004). This study investigated the relationship between online administrations' roles in identifying support services for adult learners. This investigation attempted to identify support service needs that complemented the range of adult learners' skills in e-learning communities (Flowers, 2000; Schauer-Crabb, 2002).

\section{Background of the Study}

Brown (1999), Casey (2008), Emmerson (2005), and Ullyatt (2003) discussed how distance education began with correspondence courses in 1852. The correspondence course model set the foundation for distance education to develop into current online programs. Hiltz and Turoff (2005) noted trends of online program improvements over the past 20 years like Computer Assisted Instruction (CAI) and Asynchronous Learning Networks (ALN) as social groups that enhance collaboration using technology. The advent of the revolutionary digital age, known as the technology boom, increased accessibility and expanded the potential for adult learners to engage in online programs that do not require physical presence as do traditional brick-and-mortar campuses (Hiltz \& Turoff, 2005).

Since the literature showed that e-learning continued to expand, online administrations searched for ways to remain sustainable and provided responsive online support service options for adult learners (Dare, Zapata, \& Thomas, 2005; McClure, 2007). The advent of the digital age also impacted the designs of learning programs as institutions searched for ways to improve e-learning opportunities. The simultaneous growth of the adult learner population and e-learning opportunities created a widening gap between the steady increase of adult learner needs and online support services as higher education institutions worked to attract students.

The types of regulating entities responsible for establishing standards and accreditation for distance learning programs varied for different colleges. The Council for the Advancement of Standards in higher education (CAS) had 16 standards and guidelines for Distance Education Programs (2006). Under part 14 for Educational Support Services, Academic Support Services, section L, CAS (2006) reported: 
Information concerning academic support services must be made available. Distance learning students should have opportunities for developing learning strategies and getting assistance with content comprehension. Tutoring services, supplemental instruction, and other academic support services should be available to all distance education students. These services should conform to the CAS Standards for Learning Assistance Programs in terms of their quality. (p. 168)

CAS (2006, p. 237) continued to provide standards and guidelines for The Role of Learning Assistance Programs. The extensive standards that CAS (2006) offered could supplement the development and structure of high quality online programs.

Palloff and Pratt (2003, p. 121) provided four major elements of high quality online programs: (a) effective virtual student, (b) effective course design, (c) effective online facilitator, and (d) effective student support. Although these divisions of quality online programs remain mutually dependent with each other, the scope of this study focused on Palloff and Pratt's (2003) subheadings under effective support service components for adult learners in e-learning: (a) technical support and training, (b) learner-centered, (c) offers advising, library services, registration, book store, and records. Distance learning administrations considered the value of adult learners' traits when contemplating effective student support decisions. CAS (2006, p. 159) suggested that, "distance education also poses challenges to student affairs programs and related student support services to meet the needs of distance learners even though these students may never set foot on campus."

By comprehending learners' characteristics, online support provided better learner-centered services and improved overall e-learning experiences. The growth of the adult learner population as major stakeholders in e-learning communities continued to grow. The National Center for Education Statistics (NCES) reported adult learners in the age range from twenty-four and older in online courses increased at a rate of over 50 percent (Palloff \& Pratt, 2003; Waits \& Lewis, 2003). Allen and Seaman $(2007$, p. 5) reported the online enrollment in degree-granting postsecondary institutions rising from $9.7 \%$ in 2002 to $19.8 \%$ in 2006 . These rising numbers correlated with the NCES' most recent statistical report done from the fall of 2006 through the fall of 2007 showing the simultaneous growth of adult population and postsecondary degree-granting institutions (Parsad \& Lewis, 2008). Other reports showed a $10 \%$ annual increase of distance learning growth with almost 3.5 million students enrolling in online courses since 2005 (Allen \& Seaman, 2007; Marx, 2006). The commercialization and mass approach to distance education created the need for better understanding of the profile of adult learners in e-learning.

An essential element for the success of adult learners in e-learning included understanding selfdirected learning (SDL). Merriam (2001) and Hiemstra (2003) cited Houle, Tough, and Knowles as some of the key contributors to the foundation of SDL. The contributions from Merriam (2001) and Hiemstra (2003) also offered insights that broaden SDL factors in areas of adult learning. Collaboration and guidance functioned as integral parts of developing adult learners' SDL characteristics. Adult learners refined collaborative strategies using critical thinking skills and intellectual standards (Baumgartner, 2001; Brookfield \& Preskill, 1999; Bruffee, 1999; Paul \& Elder, 1996).

Grow (1996) shared how adult learners advance through stages of self-directed learning (SSDL) with collaborative support and eventual attainment of becoming critically thinkers controlling their personal learning potential. The cultivation of critical thinking in interactive group collaboration helped adult learners liberate themselves from individual assumptions. Brookfield (1987) acknowledged, "In any group in which critical thinking was being developed group members would be engaged in identifying and challenging assumptions, and exploring ways of thinking and acting" (p. 71). The general concept that adult learners had independent self concepts and 
determined the direction of their own learning had a major function in adult learning theory. Malcom Knowles' work in adult learning theory, known as andragogy, also provided the strong movement in understanding adult learners' SDL characteristics in higher education (Merriam, 2001).

The continuing development of adult learner SDL needs with the new developments in technology warranted further investigation into online support services. Hiemstra (2003) believed "the never-ending growth of the internet and a corresponding need to develop a more inclusive future for learning that serves all people is crucial for the United States as well as the rest of the world" (p. 7). The implications of meeting the support service needs of adult learners in this virtual generation compelled institutions to remain up to date with new technologies. As adult learners increased their statistical presence, in what Proserpio and Gioia (2007) called the virtual generation demographic (v-Gen), e-learning administrations should modify services to remain in demand. Online universities found ways to serve the special needs of distance learners by developing programs that implemented distance technologies (CAS, 2006, p. 159).

\section{Statement of the Problem}

The growing changes of distance education required a better understanding of adult learners' needs for the successful future of online support services. Online administrations have struggled with gathering information to improve the online support service for adult learners (Cannon, 2001; Floyd \& Casey-Powell, 2004; Hiltz \& Turoff, 2005; Levernier, 2005; Ullyatt, 2003). The successful future of online studies required that administrations identify needs from different organizational levels. Floyd and Casey-Powell (2004, p. 61) stressed the usefulness of using a systematic approach to understanding the support service needs of adult learners.

It was not known how the selections of online support services were determined so as to enhance services for adult learners in distance learning programs. The problem of examining the strategies distance learning schools used in determining adult learners' needs was the main focus of this study.

\section{Purpose of the Study}

The purpose of this study was to examine the processes or models that helped distance learning administrations decide how to improve online support services for adult learners. The examination helped broaden the effectiveness of different adult learning models in distance education and support services. The study uncovered successful strategies that administrations could use as references to enhance support services for adult learners. The focus of this study was to synthesize the methods and processes found in current research that enriched support services for adult learners in distance education.

\section{Research Questions}

1. What did the research findings indicate in regard to how institutions implement their support services for adult learners in distance learning programs?

2. What processes did schools follow to determine what the support needs were for online adult learners?

3. What strategies emerge from the case studies that can guide the future of support services for adult learners in distance learning programs? 


\section{Nature of the Study}

The interpretive nature of the meta-ethnographic synthesis approach identified important factors of online support services for adult learners and the factors taken under consideration when adding or modifying services. A consolidation of the meta-ethnographic relationships addressed issues that adult learners found challenging and assisted in answering the research interest areas for this study. In order to conduct an in-depth qualitative review that was also temporally relevant it was necessary to narrow the focus of this research to studies completed within a five year period (2002-2006) utilizing similar research designs. These criteria resulted in five case studies suitable for analysis and synthesis.

The qualitative methodology of meta-ethnography was used as the research design for this study. Noblit and Hare's (1988, p. 78) qualitative inscribing meta-ethnographic approach guided the translation between studies done in five published case studies. The qualitative meta-ethnographic approach enabled researchers to explore relationships through interpretation of recent case studies done in online support services (Gall, Gall, \& Borg, 2003; Noblit \& Hare, 1988). The expansion of adult learners in online programs revealed how collaborative designs and other interaction methods between essential components of online educational systems ensured success for adult learners (Palloff \& Pratt, 2003; Telig, Lundy, Irani, Bielema, Dooley, Anderson, \& Raulerson, 2005 , p. 335). The unified discoveries facilitated the development of a framework to improve the identification of adult learner needs in relation to online support services in distance learning programs.

Noblit and Hare's (1988) seven phases of the meta-ethnographic approach guided the process of creating categories which led to discoveries during the interpretive stage. The process provided the following sequential steps for replication purposes: (a) phase 1-getting started, (b) phase 2deciding what is relevant to initial interest, (c) phase 3-reading the studies, (d) phase 4determining how studies are related, (e) phase 5-translating studies into one another, (f) phase 6synthesis translation, and (g) phase 7-expressing synthesis. Seidel's (2008) Ethnograph software also strengthened the coding procedure for the individual case studies and for translation between studies.

\section{Description of Methodology}

\section{Phase 1: Getting Started}

The current practices in support services for adult learners in distance learning served as the main interest of this study. Therefore, the practicality of using an electronic database or digital library such as ProQuest to locate material was suitable for this phase of the research.

\section{Data Sources and Selections}

\section{Phase 2: Deciding what is Relevant to Initial Interest}

Dissertations on distance learning from 2000-2008 functioned as the data sources for this study. The following descriptors were used to retrieve the dissertations: distance learning, adult learner, higher education, support services, improve support services, online support, meta-ethnography, case study, distance education, distance learners, adult learner perspective, and online higher education. The compilation resulted in 13 relevant dissertations. Since this research focused on distance learning support services for adult learners, the selection was reduced to qualitative dissertations that focused only on case studies. Since these case studies were completed before each 
publication, some features of the online courses may be outdated. The information can still serve as a historical framework for discussion or for designing distance learning courses. These case studies provided this research with relevant (a) descriptions, (b) explanations, and (c) evaluations of various phenomena affecting distance learning support services for adult learners (Gall et al., 2003).

Meta-ethnographic studies are highly complex, involving the informed evaluation of four or five studies that each incorporate the voices of the case study participants, the ethnographers, and meta-ethnographers (Ruth, 2005; Weed, 2008). Thus, the incorporation of the following criteria was necessary to assist in determining which case studies to use:

1. The dissertation used case studies.

2. The case study focused on distance learning education.

3. The case study included adult leaner perspectives on distance learning support services.

4. Dissertations were accessible through a digital library containing digital dissertations.

5. A maximum of five dissertations completed with distance learning graduate programs.

6. Dissertations were published between 2000 and 2008.

The audit began with the selection of dissertations that used case studies. Weed's (2008) work revealed that a meta-interpretation procedure should be transparent to guarantee the integrity and trustworthiness of the synthesis. Out of the 13 dissertations retrieved from the online database, one was excluded because the study focused on online instruction, two used surveys, two focused on faculty perspectives, and one focused on faculty perspectives of online instruction. The final selection resulted in these five case studies: (a) Flowers' (2000) work on web-based needs, (b) Nelson-Reed's (2006) work on the financial aid process, (c) Ruth's (2005) work on student services, (d) Ullyatt's (2003) work on online support systems satisfaction, and (e) Zieger's (2005) work on distance learner orientation programs and learner attrition.

\section{Phase 3: Reading the Studies}

In order to generate metaphor lists, the voices or perspectives evident in the case studies were coded. Seidel's (2008) Ethnograph version 6 software heightened the value of this study with the coding of the case studies. Seidel (1998) also noticed this cyclic process of noticing, collecting, and thinking in his descriptions of qualitative data analysis. Noblit and Hare (1988, p. 34) shared Brown, House, and Martin's criteria for establishing metaphors which assisted in maintaining objectivity when identifying metaphors for each dissertation: (a) economy-simplest concept that accounts for the phenomena and has a superior ease of representation and manipulation, (b) cogency-elegantly efficient integration, the metaphor achieves the explanation without redundancy, ambiguity, and contradiction, (c) range-power of incorporating other symbolic domains, and (d) apparency-the making apparent of connotations; the ability of language to show experience rather than refer to it.

\section{Phase 4: Determining How Studies are Related}

The application of economy, cogency, range, and apparency assisted in creating the list of objective key words to be coded by the Ethnograph (Seidel, 2008) software.

Each case study underwent the same scrutiny for coding during individual readings. Seidel's (2008) Ethnograph software classified, sorted, filed, categorized, and aided in the identification of conceptual structures. The scrutiny of each dissertation provided individual interpretation reports 
for further comparison. Each case study revealed different strategies used by the respective distance learning institution in handling areas of student support.

Distance learning institutions benefited from using different elements of organizational models that influence higher education. Barr and Desler (2000) emphasized how Kuh's contributions of organizational models in higher education had elements that distance learning institutions use. Since there was no definitive formula for managing internal structures of student affairs, higher learning institutions applied different elements of Kuh's organizational models that met institutional needs: (a) rational model, (b) bureaucratic model, (c) collegial model, and (d) political model (as cited in Barr \& Dessler, 2000, p. 122). Each dissertation focused on a specific element of a higher education institution in distance learning. Seidel's (2008) Ethnograph software coding aided in determining future direction for support services and also promoted the focus on improving services.

\section{Phase 5: Translating the Studies into one Another}

The completion of independent coding for each dissertation enabled comparisons between the individual translations. The individual translations and interpretations unraveled naturally as progression through the phases continued; "The nature of the synthesis is discovered in the process of the synthesis and aids, not supplants, the interpretation" (Noblit \& Hare, 1988, p. 80).

\section{Phase 6: Synthesis Translation}

The interpretations and relationships evident in phase five aided in determining whether relationships existed between metaphors identified in the coding structures. Clear and logical interpretations and conjectures were made when the synthesis revealed relationships between metaphors and coding structures among case studies (Bloomberg \& Volpe, 2008).

\section{Phase 7: Expressing the Synthesis}

The synthesis and connections between dissertations enabled the identification of specific knowledge that benefitted distance learning support services. The synthesis of new knowledge also added to the literature on distance education. The attempt to preserve the authors' ideas, portrayals, and representations throughout the analysis was performed. The nature of a metaethnographic synthesis provided dependability of tracking the documentation and coding of procedures through the phases. Findings were presented using a trail of information for readers to discern. The codification of the individual case studies utilizing Seidel's Ethnograph (2008) software also assisted in reporting results, as well as, relationships, omissions, and discoveries between the studies.

\section{Content Analysis with Emergent Themes}

A brief overview of each case study presented below assisted in the generation of the metaphors, themes, and elements that can serve as a general structure to guide the development of distance learning programs. The coding and definitions were guided by Noblit and Hare's (1988, p. 34) criteria. The coding and definition of terms were further analyzed utilizing Seidel's (2008) Ethnograph version 6 software. 


\section{Interpretation of Flowers (2000) Utilization-Focused Needs Assessment: A Case Study of Adult Learners' Web-Based Distance Education Needs}

Flowers's (2000) case study focused on the possible challenges of web technologies and online services that the University of Alabama's School of Continuing Education's Adult Interdisciplinary Studies (AIS) faced in preparation to go online. The author used the utilization-focused needs assessment to reveal internal and external stakeholders' questions regarding the adoption and change to a Web Based Distance Education (WBDE) in these six areas: (a) management, (b) staffing, (c) pedagogy, (d) learner, (e) technology, and (f) evaluation. The author further organized the six areas using three common sub-headings: (a) context, (b) process, and (c) product. The stakeholders involved with the study included AIS learners, faculty, instructional designers, support staff, web experts, and vendors. The author's study found commonalities between stakeholders' questions that focused on the first year start-up phase of WBDE, facilitating on-going program improvement, and priority needs of AIS students. The stakeholders' contributions supplied the author with insights on the University of Alabama's School of Continuing Education program for adult learners.

The utilization approach ascertained fundamental necessities from internal and external stakeholders in distance learning. The Utilization-Focused approach identified needs from all stakeholders in the architectural make-up of Web Based Distance Education. The determination of specific stakeholder needs supplied valuable information for instructional designers and vendors. There was an obvious discrepancy between vendors and faculty members' perceptions of training. Vendors attempted to supply the demand for training but faced low faculty attendance. Faculty members had different worries and expectations related to distance learning. They were more concerned with creating a nurturing environment with their global classroom. The input generated from all stakeholders' ideas benefited the development and alignment of meeting distance learning needs.

Vendors recognized the desire and need for faculty training on instructional software. Yet, the low attendance rates were surprising. Could the low attendance have been due to funding since teaching online courses were voluntary? How could the AIS department have motivated online faculty to receive new software training? Should the AIS administration have offered compensation to online faculty to attend the vendor training? Should the online faculty be paid for taking the additional time to learn the new software? How could the AIS administration have motivated faculty to learn new technology and reduce the initial disruption when adopting new programs or technologies for integration into the web environment?

The digital divide and questions of equitable access to online service were evident in this author's study. She found that $13 \%$ of enrolled students and $12 \%$ of students who have not attended classes in the past 18 months, called stop-out students, utilized the public library as their primary source of computer access. These results reinforced the internet access disparity evident amongst learners. Her study also showed that funding concerns and obligation to support web-based distance education remained significant concerns.

In light of these findings, several questions emerged. Whose duty is it to supply students with computers and equitable technology access? Do institutions limit learning to only those who own computers? How do institutions reduce the digital divide? How does a nation screen for technology readiness and reduce the digital divide?

The obvious digital divide between Black's and Caucasian's technology skills and access to technology was an alarming revelation. All learners displayed ambition to continue their education by 
pursuing AIS programs and found ways to meet the demands of web-based distance education. These motivated students' needs must be met. The identification of the range of learners' technology needs should keep attrition numbers low. Her establishment of possible reasons why females and blacks leave their academic programs should help AIS administrators establish proactive approaches to reducing attrition rates.

\section{Interpretation Nelson-Reed (2006) Distance Education and the Financial Aid Process: A College Student's Perspective}

Nelson-Reed's (2006) study focused on 16 distance learning students' perspectives of the financial aid process. These students were enrolled in three different institutions and received compensation for participating in the study. This author presented Title IV funds history and progression. The advancement of Title IV funds changing qualification rules facilitated the increase and ability for learners to pursue degrees in higher education. The participants from this case study engaged in three, one-hour focus group discussions. The discussions used open-ended questions to guide the discussions. The focus group discussions were held in Columbia, South Carolina and other locations.

The intentions of distance learning institutions to improve academic delivery and service delivery require feedback from learners. For example, the author suggested that financial student services were one critical area where student perceptions must be explored for program and policy improvement. The participants communicated their needs for improved financial aid services for online FAFSA guidance, submission reviews, and knowledgeable personnel. The results of the author's study also highlighted the overall need for personal interaction and communication for a successful distance education program.

How realistic are the distance learners' expectations to receive comparable financial aid service online? Are the traditional on-site financial aid services even replicable online? Should Title IV funds include the staffing costs for financial aid employees to function as live-chat representatives who are readily available $24 / 7$ or after traditional working hours?

The complexity of financial opportunities and the financial aid process seemed like a major necessity. Should universities offer financial aid information courses or classes? Could financial aid classes focus on different areas of assistance like scholarship information class, scholarships for minorities, scholarships for specific expertise areas, etc.?

The online FAFSA submission data collected showed that distance education institutions who offered over $50 \%$ their courses online enabled more students to receive financial aid and attend their institutions. How do distance learning institutions ensure the quality of online course delivery in order to meet Title IV eligibility requirements?

\section{Interpretation of Ruth (2005)}

\section{An Investigation into the Need for Co-Curricular Student Services for Distance Education Students}

Ruth (2005) assessed the types of co-curricular student services needed for distance learning students to determine ways in which these services may be implemented at Drexel University College of Nursing and Health Professions. Online questionnaires for students on the Center City Hahnemann Campus and interviews with faculty and administrators of the College of Nursing and Health Professions provided specific information on ways to improve Drexel University's support services. 
The author reiterated the need for student affairs administrations to take on a customer service approach throughout the paper. He summarized that a customer service approach to student affairs would improve services for a growing virtual student population. The author suggested that the results "may be used as a part of the strategic planning process for developing, implementing, and refining the types of services offered to online students and to further develop the changing role of the student affairs professional" (Ruth, 2005, p. 94).

The adult learners who participated in the research revealed areas that Drexel University's College of Nursing and Health Professions could utilize when prioritizing services for distance learners. Administrators need to remain aware of the different distance learner groups when planning ways to make distance programs more appealing for prospective students. Distance learning administrations need to find ways to attract and retain learners. The author collected data on groupspecific needs that could draw the attention of prospective learners. He shared how AfricanAmerican or gay students within the student population faced barriers in developing and transitioning into the distance learning environment. These prospective learners functioned as potential customers who sought services between distance learning institutions. Therefore, continuous efforts by distance learning institutions to improve identification of clientele needs increased their chances to expand enrollment. This stresses an important question: How do distance learning institutions find ways to meet the changing needs of the "evolving" distance learner populations?

\section{Interpretation of Ullyatt (2003) Satisfaction of Students and Administrators Toward Support Systems in Online Degree Programs: A Case Study}

Ullyatt (2003) investigated student and administrator satisfaction with the functions of enrollment services and the current model's effectiveness as a service system to online graduate students at SetonWorldWide online campus for Seton Hall University. Her case study used online surveys administered to SetonWorldWide online students enrolled in the Masters of Education program, Master of Science in Nursing program, and SetonWorldWide and Enrollment Services administrators at Seton Hall University from June and July 2002.

This author's study revealed disparity between what distance education learners and administrators found important. Learners wanted registration representatives available after traditional working hours instead of being on hold or reaching full voicemail boxes. They wanted direct contacts for enrollment services. In contrast, the enrollment services administrators and SetonWorldWide's administrators held different views of areas that needed attention and improvement. Unlike the learners consumed with financial and billing, administrators were more concerned with admissions and registration topics. They recommended that a centralized data entry process for applications would improve the accuracy and completeness of student accounts. Administrators also felt additional staff that functioned at an intermediary level within the admissions division would reduce the tasks currently duplicated by personnel. The author suggested that defined roles of intermediary personnel assisting learners in meeting deadlines and completing formal matriculation forms would improve learners' perceptions of services.

The disparity between learners and administrative participants' views supplied SetonWorldWide with useful information on ways to improve registration, billing, financial aid, and admissions procedures. Regardless of the disparity in responses, the data accumulated from research participants presented useful details for administrations to consider. 


\section{Interpretation of Zieger (2005)}

The Relationship Between Student Orientation Programs that Support Community Building and Retention of Distance

\section{Learners}

Zieger (2005) investigated how the Crossroads orientation program assisted in overcoming attrition rates in Sewanois University's Graduate School of Education. The participants were learners enrolled in the Doctor of Education (EdD) Educational Technology program. She analyzed two consecutive years of these learners' views of the Crossroads orientation program. As a result, she was able to share insight on the orientation programs' relevance of the instructional goals as well as participants' learning experiences and the relationship with learner retention. This mandatory program allowed learners to meet in real time to establish rapport with each other and their respective group leaders.

The examination of Sewanios University's Crossroads orientation program revealed significant correlations between establishing learner relationships and learner success. The Crossroad's orientation program included the use of the backward design to develop goals and activities. The backward design assisted the Crossroad's development team in creating structured goals that assisted learners in acclimating to their distance learning doctoral program expectations. The rapport established between learners and program coordinators or counselors appeared to provide strong foundations for meaningful relationships. These relationships enabled learners to bond and assist each other through their programs. Community building and relationships were integral in the backward design goals for the orientation program. The author noticed the implication and importance to meet the specific needs of online learners using the backward design for Sewanois University's Crossroad orientation program.

\section{Discussion of Main Findings}

This section described the synthesis and overarching themes between the five case studies and connection to the research questions as noted in Table 1.

Table 1. Case study themes and elements by author

\begin{tabular}{|l|c|c|c|c|c|c|}
\hline Framework Elements & Flowers & $\begin{array}{c}\text { Nelson- } \\
\text { Reed }\end{array}$ & Ruth & Ullyatt & Zieger & Total \\
\hline \multicolumn{1}{|c|}{ Web-Based Design } & & & & & & \\
\hline Designing Frameworks & 3 & 2 & 1 & 4 & 3 & 13 \\
\hline Learner Orientation & 1 & 1 & 5 & 1 & 3 & 11 \\
\hline Theories & 6 & 1 & 4 & 1 & 1 & 13 \\
\hline Technical Access & 3 & 1 & 3 & 2 & 2 & 11 \\
\hline Types of Distance Education & 0 & 0 & 0 & 5 & 0 & 5 \\
\hline \multicolumn{1}{|c|}{ Student Support Services } & & & & & & \\
\hline Library Services & 0 & 0 & 1 & 0 & 0 & 1 \\
\hline Technical Support & 0 & 1 & 3 & 0 & 1 & 5 \\
\hline Academic Advisement & 0 & 0 & 1 & 0 & 1 & 2 \\
\hline Registration & 0 & 0 & 0 & 1 & 0 & 1 \\
\hline Billing & 0 & 0 & 0 & 1 & 0 & 1 \\
\hline Financial Aid & 2 & 4 & 0 & 1 & 0 & 7 \\
\hline Admissions Procedures & 0 & 0 & 0 & 1 & 0 & 1 \\
\hline
\end{tabular}




\begin{tabular}{|l|c|c|c|c|c|c|}
\hline Framework Elements & Flowers & $\begin{array}{c}\text { Nelson- } \\
\text { Reed }\end{array}$ & Ruth & Ullyatt & Zieger & Total \\
\hline \multicolumn{1}{|c|}{ Stakeholder Perceptions } & & & & & & \\
\hline Adult Learners & 4 & 3 & 0 & 3 & 2 & 12 \\
\hline Faculty & 3 & 0 & 0 & 0 & 2 & 5 \\
\hline Support Staff & 2 & 0 & 0 & 0 & 0 & 2 \\
\hline Administrators & 2 & 2 & 2 & 4 & 0 & 10 \\
\hline Ethnic Groups & 2 & 1 & 1 & 0 & 0 & 4 \\
\hline Instructional Designers & 3 & 0 & 0 & 0 & 1 & 4 \\
\hline Vendors & 2 & 0 & 0 & 0 & 0 & 2 \\
\hline \multicolumn{1}{|c|}{ Learner Attrition } & & & & & & \\
\hline Reducing & 1 & 1 & 2 & 0 & 1 & 5 \\
\hline
\end{tabular}

What did the Research Findings Indicate in Regard to how Institutions Responded to Their Support Services for Adult Learners in Distance Learning Programs?

The research findings revealed that the institutions involved in the five case studies for this metaethnography responded to support services with stakeholder input, compensation for participation to gather learner perspectives on the financial aid process, orientation materials, specific personnel for online programs, and orientation programs. Flowers's (2000) work at the University of Alabama's School of Continuing Education Adult Interdisciplinary Studies sought input from stakeholders for overall web based instruction. Nelson-Reed (2006) offered compensation to participants for their perspectives on the financial aid process. Ruth's (2005) work at Drexel University's College of Nursing and Health Professions offered orientation material as a download or a CD-ROM and a Blackboard Tutorial. Drexel University also supplied their adult learners with Microsoft's Office software, Microsoft Word, Excel, Access, Outlook, and Power Point. Whereas, Ullyatt's (2003) study focused on specific personnel that supported graduate learners. Zieger (2005) investigated the Crossroads orientation program at Sewanois University's Graduate School of Education. The stakeholder input, financial aid process perspectives, orientation material, face to face orientation goals, and personnel support were strategies that responded to distance learners' support service needs.

\section{What Processes did Schools Follow to Determine What the Support Needs Were for Online Adult Learners?}

Each researcher presented approaches and processes in identifying specific support needs for learners in Tables 2 and 3. These methods enabled respective researchers to gather specific information on needs and perceptions in relation to distance learning and the needs of learners in online support services. 
Table 2. Data collection methods listed by author

\begin{tabular}{|l|c|c|c|c|c|}
\hline Procedure/Process & Flowers & $\begin{array}{c}\text { Nelson- } \\
\text { Reed }\end{array}$ & Ruth & Ullyatt & Zieger \\
\hline Email interviews & 1 & & & & \\
\hline Face-to-face interviews & 1 & 1 & 1 & & \\
\hline Telephone interviews & 1 & & & & \\
\hline Focus groups & 1 & 1 & & 1 & \\
\hline Questionnaire & 1 & 1 & 1 & & 1 \\
\hline Secondary data analyses & 1 & & & & 1 \\
\hline Quantitative statistical data & 1 & & & & \\
\hline Survey & & & & 1 & 1 \\
\hline Scale & & & & & 1 \\
\hline
\end{tabular}

Table 3. Processes schools followed in determining distance learners support needs

\begin{tabular}{|l|l|l|}
\hline Author & \multicolumn{1}{|c|}{ School/s } & \multicolumn{1}{c|}{ Processes } \\
\hline Flowers & $\begin{array}{l}\text { University of Alabama's } \\
\text { School of Continuing } \\
\text { Education's Adult Inter- } \\
\text { disciplinary Studies (AIS) }\end{array}$ & $\begin{array}{l}\text { Flowers used the utilization-focused needs assessment to } \\
\text { gather input from stakeholders for recommendations to } \\
\text { begin web based instruction. Stakeholders consisted of AIS } \\
\text { learners, faculty, instructional designers, support staff, web } \\
\text { experts, and vendors. Stakeholders provided input regard- } \\
\text { ing adoption and change to Web Based Distance Education } \\
\text { in six areas: (a) management; (b) staffing; (c) pedagogy; } \\
\text { (d) learner; (e) technology; and (f) evaluation. Flowers } \\
\text { (2000) further organized the six areas using three common } \\
\text { sub-headings: (a) context; (b) process; and (c) product. }\end{array}$ \\
\hline $\begin{array}{l}\text { Nelson- } \\
\text { Reed }\end{array}$ & $\begin{array}{l}\text { Three higher learning } \\
\text { institutions in the United } \\
\text { States eligible to offer } \\
\text { Title IV financial aid. }\end{array}$ & $\begin{array}{l}\text { Nelson-Reed created a questionnaire for focus group dis- } \\
\text { cussions to find relationships between financial aid and } \\
\text { learner retention or attrition. Participants were recruited } \\
\text { through flyers and announcements. Participants received } \\
\text { compensation for their contributions. Each focus group } \\
\text { answered open-ended questions in one-hour interviews at } \\
\text { neutral locations. }\end{array}$ \\
\hline Ruth & $\begin{array}{l}\text { Drexel University's Col- } \\
\text { lege of Nursing and } \\
\text { Health Professions }\end{array}$ & $\begin{array}{l}\text { Ruth used an online questionnaire, existing student infor- } \\
\text { mation, and interviews with faculty and administration to } \\
\text { determine what types of co-curricular student services } \\
\text { needed attention to improve student affairs support ser- } \\
\text { vices. }\end{array}$ \\
\hline Ullyatt & $\begin{array}{l}\text { Seton Hall University's } \\
\text { SetonWorldWide (SWW) } \\
\text { online campus }\end{array}$ & $\begin{array}{l}\text { Ullyatt used online surveys and focus groups to gather in- } \\
\text { formation on learners' satisfaction of enrollment service } \\
\text { effectiveness from SWW's Masters of Education Admini- } \\
\text { stration and Supervision, Master of Counseling, Master of } \\
\text { Arts in Strategic Communication and Leadership, Master } \\
\text { of Healthcare Administration, Master of Science in Nurs- } \\
\text { ing program, and SWW and Enrollment Services Adminis- } \\
\text { trators. }\end{array}$ \\
\hline
\end{tabular}




\begin{tabular}{|l|l|l|}
\hline Author & \multicolumn{1}{|c|}{ School/s } & \multicolumn{1}{c|}{ Processes } \\
\hline Zieger & $\begin{array}{l}\text { Sewanois University's } \\
\text { Graduate School of Edu- } \\
\text { cation Crossroads orien- } \\
\text { tation program }\end{array}$ & $\begin{array}{l}\text { Zieger collected data using Rovai's Classroom Community } \\
\text { Scale to measure students'sense of community in the Edu- } \\
\text { cational Technology program, surveys for statistical demo- } \\
\text { graphics, questionnaires, university schedules, and post- } \\
\text { orientation survey data to find any correlation with the } \\
\text { Crossroads orientation program and attrition rates. }\end{array}$ \\
\hline
\end{tabular}

\section{What Concepts or Themes Emerge from the Dissertation Studies that can Guide the Future of Selecting a Good Model for Online Support Services for Adult Learners in Distance Learning Programs?}

The translation and syntheses of these case studies resulted in four general themes with associated core elements and details as seen in Table 4. The collection of themes and elements emphasized areas that could provide guidance when distance learning institutions need to make decisions. The syntheses showed that collaborative efforts in the decision making process generated productive outcomes. The collaborative efforts also identified areas that need attention.

Table 4. Four general themes with associated elements and details

\begin{tabular}{|c|c|}
\hline Themes/Elements & Details \\
\hline \multicolumn{2}{|l|}{ Web-based design } \\
\hline Designing Frameworks & $\begin{array}{l}\text { Utilization-Focused needs assessment approach begins the design and } \\
\text { helps implement an improvement-focused formative evaluation plan, } \\
\text { Stufflebeam's Context, Input, Process, and Product (CIPP) model of } \\
\text { evaluation, Rovai's Classroom Community Scale, Levitz's Student } \\
\text { Satisfaction Inventory, Brotherson's (1994) six point components for } \\
\text { using interactive focus groups, Malcolm Baldrige Criteria to Evaluate } \\
\text { Service quality of administrators of higher education, Kanji and Tam- } \\
\text { bi's Business Excellence Model (as cited in Tambi, Ghazali, \& Ya- } \\
\text { hya 2008), Chickering and Gamson's Principles of Good Practice, } \\
\text { Distance Learning Principles, National Education Association and } \\
\text { Benchmarks for Success in Internet-Based Distance Education, Archi- } \\
\text { tectural infrastructure with feedback on learner effectiveness, Deter- } \\
\text { minants of Service Quality }\end{array}$ \\
\hline Learner Orientation & $\begin{array}{l}\text { Cohorts, Orientation programs, backward design and program goals, } \\
\text { determining learner readiness, word processing software and tutorials, } \\
\text { establishing learner community connections, female perceptions on } \\
\text { interaction, male perspectives on interaction, ethnic-specific discover- } \\
\text { ies, learners sexual orientation concerns }\end{array}$ \\
\hline Technology Access & New technology, determining learners' internet accessibility \\
\hline Theories & $\begin{array}{l}\text { Constructivist theory, Grounded theory, Charles Wedemeyer's Theory } \\
\text { of Independent Study, Michael Moore's Theory of Independent Study } \\
\text { or Theory of Transactional Distance, Otto Peters' Theory of Industri- } \\
\text { alization of Teaching or Mass Education and Supplemental Teaching } \\
\text { Aids, Borje Holmberg's Theory of Interaction and Communication or } \\
\text { Separation of Teacher and Learner, Keegan's Theoretical Framework } \\
\text { for Distance Education, Student Development Theory }\end{array}$ \\
\hline
\end{tabular}




\begin{tabular}{|c|c|}
\hline Themes/Elements & Details \\
\hline $\begin{array}{l}\text { Types of Distance } \\
\text { Education }\end{array}$ & $\begin{array}{l}\text { Single-mode organizations, Dual-mode, Specialized service organiza- } \\
\text { tions, Networks or networking bodies, Training and Continuing Edu- } \\
\text { cation or Professional Development Center model }\end{array}$ \\
\hline \multicolumn{2}{|l|}{$\begin{array}{l}\text { Student support } \\
\text { services }\end{array}$} \\
\hline Library Services & navigation skill \\
\hline Technical Support & 24/7 availability \\
\hline Academic Advisement & improving connections \\
\hline Registration & Automation, timelines \\
\hline Billing & Automation, timelines \\
\hline Financial Aid & $\begin{array}{l}\text { Customer service, policy and practice, demographics, Free application } \\
\text { for federal student aid, types of financial aid }\end{array}$ \\
\hline Admissions Procedures & Steps, form requirements, timelines \\
\hline \multicolumn{2}{|l|}{ Stakeholder perceptions } \\
\hline Adult Learners & $\begin{array}{l}24 / 7 \text { assistance, faculty interaction, human approach, sense of com- } \\
\text { munity, personalizing services }\end{array}$ \\
\hline Faculty & $\begin{array}{l}\text { Desire for learner contact beyond course room, automation of ser- } \\
\text { vices, fear of losing promotions, intellectual property }\end{array}$ \\
\hline Support Staff & $\begin{array}{l}\text { Customer service approach, desire for automation of services, col- } \\
\text { laboration with faculty and administration, desired more training to } \\
\text { meet learners' needs }\end{array}$ \\
\hline Administrators & $\begin{array}{l}\text { Managing web-based education, appropriate assessments, dealing } \\
\text { with assessment results }\end{array}$ \\
\hline Ethnic Groups & $\begin{array}{l}\text { Reducing the digital divide of technology skills and access to technol- } \\
\text { ogy }\end{array}$ \\
\hline Instructional Designers & $\begin{array}{l}\text { Alignment of faculty desires and institutions' learning expectations, } \\
\text { willingness to facilitate change while recognizing adult learner char- } \\
\text { acteristics }\end{array}$ \\
\hline Vendors & $\begin{array}{l}\text { Alignment of software with institutions' needs, low faculty training } \\
\text { attendance }\end{array}$ \\
\hline \multicolumn{2}{|l|}{ Learner Attrition } \\
\hline Reducing & $\begin{array}{l}\text { College affordability, identify gender and ethnicity relation to attrition } \\
\text { numbers, learner preparedness through training and improvement of } \\
\text { skills }\end{array}$ \\
\hline
\end{tabular}

\section{Conclusions and Findings}

The consistent progression in the technology field and potential of globally educating adult learners through web-based instruction expanded the marketability of higher education. In order to participate in this trend, administrations must be equipped with expertise in different fields. Distance learning experts, software vendors, faculty, learners, support staff, and administrators worked collaboratively with researchers to generate data that supported the developments or improvements of support structures essential to surviving in the distance learning market. The data presented in this study came from recent case study dissertations on case studies that focused only on support services. The information from these case studies contributed valuable data needed to synthesize qualitative data. 
The combination of Noblit and Hare's (1988) meta-ethnographic approach with Seidel's (2008) Ethnograph version 6 software helped in completing the synthesis process. The reading, coding, interpretation of each case study, and synthesis between the dissertations promoted the identification of common themes associated with distance learning support services for adult learners. The synthesis of the data on adult learners needs in distance learning revealed four general themes: (a) web-based design, (b) student support services, (c) stakeholder perceptions, and (d) learner attrition. This particular audience of adult learners represented the student population seeking graduate degrees in a range of fields. They were at least 25 years old with adult responsibilities such as: full-time work careers, family needs, and distantly located (Flowers, 2000; Nelson-Reed, 2006; Ruth, 2005; Ullyatt, 2003; Zieger, 2005). Since adult learners had specific characteristics, the perspectives from the five case studies were credible resources because of their actual school experiences with distance learning support service areas.

The growing adult learner population and the range of emerging technologies affected the approaches to distance learning and web based education designs. As technologies developed, learners' range of media preferences also expanded (Sims, 2008). New and effective technology tools supplied levels of interaction for learners' media preferences. The use of funds provided opportunities for professional growth, updated support services, improved support service personnel skills, and identified assessments for determining learners' needs. Maintaining professional development built receptiveness to revisit current practices within the student support architectural framework. Restructuring distance learning support services required understanding the components involved with web-based learning designs.

The multiple perspectives presented in this study revealed common concerns regarding components of web-based distance education designs. Although the information shared here only represented a small portion of research on adult learners and distance education, the material can be applied to future work related to the evolution and improvement of support services. The information can also be utilized by distance learning communities to meet their specific institutions' purposes. Regardless of the level that distance learning institutions functioned in the scope of implementing distance learning support services, appropriate assessments gathered essential data to make decisions for improvement.

\section{Finding 1. Web-based Education Theory and Design}

Theoretical foundations should be considered when designing web-based education to meet the advancements in technology that also complement adult learners' needs. Kapp's and Knowles' work described the five distinctive qualities in adult learning theory, known as andragogy, which has promoted self-directed learning strategies in higher education (Merriam, 2008; Zemke, 2002). The need for acknowledging and addressing the unique andragogical traits of self-directed adult learners while combining learner-centered constructivist principles in distance learning environments supported theoretical foundations (Tuquero, 2010). Each case study selected for this metaethnographic study supported the basic andragogical and constructivist principles of implementing learner-directed approaches. These theory-based approaches in distance learning go beyond understanding adult learners' perceptions and expectations.

Organizations interested in developing or improving distance education should consider the five elements associated with web-based design that emerged from the synthesis: (a) assessments for designing, (b) learner orientation, (c) theories, (d) technology access, and (e) types of distance education. Ullyatt (2003) and Tuquero (2010) noted the five types of distance education which serve different purposes for learning communities' needs. Upon identifying the type of educational service that will be provided, organizations could design distance learning program goals based on appropriate theoretical foundations that meet online accrediting authorities' standards. 
The goals and steps to complete programs should be presented to learners in some form of learner orientation. The relationships that begin during orientations between distance learning organization members and learners establish strong community foundations. These strong connections between distance learning members who maintain correspondence with learners provide essential support that learners need to complete programs which can reduce attrition rates in distance education programs.

\section{Finding 2. Stakeholder Input and Perceptions}

The importance of diagnosing stakeholder needs required direct input from all participants involved in web-based education. The importance of acknowledging stakeholders' needs has enhanced the progression of support services in adult education. The participants' views reviewed in these different support service areas upheld how support services continued to develop in distance learning.

Other perceptions came from stakeholders at the administrative level, faculty level, or support level. Stakeholders' input for the improvement of web-based instruction identified distinct focus areas for training. Administrators wanted to remain marketable and sought ways to increase possibilities to improve the potential to recruit and retain distance learners. Vendors supported administrators and valued input from stakeholders to create desirable software products that would be user-friendly. Vendors also wanted to provide faculty training on the software. Faculty wanted more training and meaningful connection opportunities with distance learners. Support staff also wanted to improve their skills to service faculty and learners better.

Each school determined support service needs for adult learners in different disciplines through a variety of methods. Questionnaires were the most popular method of gathering information used by four out of the five schools involved in this study. Three schools incorporated face-to-face and focus groups. Two schools used secondary data analyses with surveys. Whereas, one school used email interviews; one school used telephone interviews; one school used scales; and one school used quantitative statistical data. Flowers (2000) used the utilization-focused needs assessment to gather stakeholder input. Nelson-Reed (2006) created a questionnaire for focus groups. Ruth (2005) used an online questionnaire, student information, and interviews. Ullyatt (2003) used online surveys and focus groups. Zeiger (2005) integrated the Rovai's Classroom Community Scale, surveys, questionnaires, and secondary data. Multiple readings of the dissertations using Noblit and Hare's (1988) meta-ethnographic approach as a guide and Seidel's (2008) Ethnograph version 6 software resulted in four general themes and elements that can guide the development of distance learning support services. They were: (a) web-based design, (b) student support services, (c) stakeholder perceptions, and (d) learner attrition.

Stakeholders' input supplied crucial information for the identification of areas that need attention to improve web-based design. The stakeholders' perspectives came from administrators, learners, faculty, instructional designers, support staff, web experts, and vendors. The stakeholders' participation in the individual studies for this synthesis supplied in-depth data that should improve individual institutions' distance learning programs and expand on the overall views of support services as well. The authors from this synthesis shared strategies used to gather data from stakeholders listed in earlier in Table 2. Tuquero (2010) also listed Flowers' suggestions to maximize researchers' time spent gathering data and ways to improve interviews and questionnaires. Organizations can make adjustments to these suggestions when seeking input from stakeholders to improve or start distance learning programs. 


\section{Finding 3. Support Services}

Student support services encompassed different areas of focus throughout this study. Wellplanned orientation programming was evident with Zieger's (2005) study of Sewanios University's Crossroads orientation program design; this program's content assisted in generating specific goals and supporting activities to expose learners to the rigors of distance learning. Software programs and tutorials supported students' competency navigating through web-based sites and increased technological proficiency necessary for success in online programs. The requirement of face to face orientations at respective institutions established early relationships with fellow learners and faculty and exposed learners to program expectations. Ullyatt's (2003) work revealed Seton Hall University's attempt to equip distance learners with direct support from administrators. These administrators specifically catered to admission, registration, billing, and financial aid issues. Automation of services would speed the process of student account information, increase accuracy, and reduce redundancy between personnel.

Flowers (2000) focused on identifying needs to begin web-based instruction. Nelson-Reed (2006) sought financial aid information. Ruth (2005) ranked co-curricular student services into categories of importance. Ullyatt's (2003) study demonstrated collaborative efforts in establishing specific administrative support services for distance learners but still encountered dissatisfaction. Zieger (2005) concentrated on the relationship between orientation programs and learner retention. The elements synthesized from the studies revealed the need for readily available learner assistance in addition to automated services listed earlier in Table 4.

Distance learning organizations can combine support service models and web education design suggestions to find ways to meet these student support service needs. Floyd and Casey-Powell's (2004) Inclusive Student Services Model presented a framework of five phases that categorize learners' needs: (a) learner intake phase, (b) learner intervention phase, (c) learner support phase, (d) learner transition phase, and (e) measurement phase. These phases can be combined with Flowers' (2000) Essential Web Education basics when designing ways to support learners as they progress through their programs.

\section{Finding 4. Learner Attrition}

The synthesis proved how distance learning institutions recognized the need to concentrate on reasons why learners withdrew early and failed to complete programs (Nichols, 2010; Ullyatt, 2003; Zieger 2005). The exploration of these dissertations revealed that building strong relationships with learners and maintaining a human connection with the university increased successful completion of programs. LaPadula's (2003) categories of online student services could provide learners with other avenues to help complete program requirements in lieu of withdrawing: (a) academic advising/career counseling, (b) personal/mental health counseling, and (c) services that promote a sense of community. Distance education personnel in these areas can work together with students who need additional support to overcome issues they may be facing and decrease withdrawal rates from programs.

The research shows that leaders who remain open to the changing needs of distance learners can adjust program designs and implementation through collaborative efforts. These team efforts support the progression and program effectiveness through direct input from all stakeholders (Rovai, Ponton, \& Baker, 2008; Vai \& Sosulski, 2011). The relationship between successful online programs and learner retention stems from collaborative efforts between leadership, content experts, instructional designers, and learners. Rovai, Ponton, and Baker (2008) highlighted the necessity of a team approach to developing courses. 
It is simply unrealistic, and a poor use of resources, to expect a faculty member to be content expert, web developer, multimedia designer, and systems administrator all rolled into one....In a team approach, the faculty member is partnered with one or more instructional designers and multimedia developers. These individuals should be well trained in their field and bring a customer-focused attitude toward their work. (p. 71)

The customer oriented learning institution will remain attractive to learners seeking out programs that meet their needs. Learner attraction and retention in distance learning requires input from learners an instructional designers who make adjustments based on the changing needs of the students through feedback and communication which Vai and Sosulski (2011) shared.

Universities and schools increasingly require that academic achievement be determined in terms of learning outcomes. It is terrific public relations for a teacher, trainer, program, or institution to declare that they can provide a specific set of skills and/or a specific level of academic achievement for their learners. This provides a check on the program. Educational institutions and companies that deliver on their promises graduate learners of a quality that fully supports their success in their chosen field or profession. (p. 183)

The team effort offers multiple perspectives that enable instructional designers to develop meaningful courses based on constructivist and andragogical principles. These theoretical principals in distance learning communities uphold learner-centered outcomes.

\section{Summary}

This study provided an analysis of internal accounts from universities interested in distance learning support services. The synthesis of close-up views generated these four major themes that can supply insight for institutions to enhance distance learning opportunities and services: (a) webbased design, (b) support services, (c) stakeholder perspectives, and (d) learner attrition. Supplying optimal learning opportunities for adult learners requires consistent monitoring of needs and changes in web-based education through collaboration with different stakeholders involved with technological advancements and applications in higher education. Adult learners have essential roles in the distance learning market and will remain a substantial factor when focusing on the collaborative nature of web-based education. The synthesis presented in this study serves as an overview of some fundamental perspectives that distance learning institutions can use to guide decisions for improving support services for adult learners. The findings and suggestions shared here can serve as a starting point to enhance web-based education designs.

\section{References}

Allen, I. E., \& Seaman, J. (2007). Online nation: Five years of growth in online learning. Needham, MA: Sloan Consortium.

Barr, M. J., \& Desler, M. K. (2000). The handbook of student affairs administration: A publication of the national association of student personnel administrators. San Francisco: Wiley.

Baumgartner, L. M. (2001). An update on transformational learning. In S. Merriam (Ed.), New directions for adult and continuing education: The new update on adult learning theory (pp. 15-24). Hoboken, NJ: Wiley.

Bloomberg, L. D., \& Volpe, M. V. (2008). Completing your qualitative dissertation: A roadmap from beginning to end. Thousand Oaks, CA: Sage Publications, Inc.

Brookfield, S. D. (1987). Developing critical thinkers: Challenging adults to explore alternative ways of thinking. San Francisco: Jossey-Bass.

Brookfield, S. D., \& Preskill, S. (1999). Discussion as a way of thinking. San Francisco: Wiley. 
Brown, H. (1999). The rhetoric of distance education. (Ph.D. dissertation, Texas Woman's University, Houston,Texas) Retrieved July 21, 2008 from Dissertation \& Theses: Full Text database (AAT 99444488)

Brotherson, M. (1994). Interactive focus group interviewing: A qualitative research method in early intervention. Topics in Early Childhood Special Education, 14(1), 101. Retrieved June 15, 2011 from EBSCOHost database.

Bruffee, K. (1999). Collaborative learning (2nd ed). Baltimore, MD: John Hopkins University Press.

Cannon, M.P. (2001). Internal support systems essential to faculty success in distance delivery education programs. (Ed.D. dissertation, Oregon State University, Corvallis, Oregon) Retrieved March 19, 2008 from ProQuest Digital Dissertations database. (AAT 3015199)

Casey, D.M. (2008). A journey to legitimacy: The historical development of distance education through technology. TechTrends: Linking Research \& Practice to Improve Learning, 52(2), 45-51. Retrieved April 11, 2009 from Academic Search Premier database.

Conrad, R., \& Donaldson, J. (2004). Engaging the online learner: Activities and resources for creative instruction. Hoboken, NJ: Wiley.

Council for the Advancement of Standards in Higher Education. (2006). CAS professional standards for higher education (6th ed.). Washington, DC: Author.

Dare, L., Zapata, L., \& Thomas, A. (2005). Assessing the needs of distance learners: A student affairs perspective. New Directions for Student Services, 112, 39-54. Retrieved July 23, 2008 from Academic Search Premier database.

Emmerson, A. M. (2005) A history of the changes in practices of distance education in the United States from 1852--2003. (Ed.D. dissertation, Dowling College, Oakdale, New York) Retrieved March 18, 2008 from Dissertations \& Theses: Full Text database. (AAT 3157941)

Fischer, M., \& Baird, D. (2006). Making mLearning work: Utilizing mobile technology for active exploration, collaboration, assessment, and reflection in higher education. Journal of Educational Technology Systems, 35(1) 3-30. Retrieved May 21, 2008 from EBSCOHost database.

Flowers, D. J. (2000). Utilization-focused needs assessment: A case study of adult learners' web-based distance education needs. (Ph.D. dissertation, University of South Alabama, Mobile, Alabama) Retrieved March 18, 2008 from ProQuest Digital Dissertations database. (AAT9975867)

Floyd, D., \& Casey-Powell, D. (2004). New roles for student support services in distance learning. New Directions for Community Colleges, 2004(128), 55-64. Retrieved July 22, 2008 from Academic Search Premier database.

Gall, M. D., Gall, J. P., \& Borg, W. R. (2003). Educational research: An introduction (7th ed.). White Plains, NY: Longman.

Garrison, D. R., \& Cleveland-Innes, M. (2005). Facilitating cognitive presence in online learning: Interaction is not enough. The American Journal of Distance Education, 19(3), 133-148. Retrieved July 29, 2008 from Academic Search Premier database.

Gipps, C. V. (2005). What is the role for ICT-based assessment in universities? Studies in Higher Education, 30(2), 171-180. Retrieved July 24, 2007 from EBSCOHost database.

Grow, G .O. (1996). Teaching learners to be self-directed. Adult Education, 41(3), 125-149. Retrieved July 25, 2007 from http://www.longleaf.net/grgrow/SSDL/Model.html

Hiemstra, R. (2003). More than three decades of self-directed learning: From whence have we come? Adult Learning, 14, 5-8. Retrieved July 28, 2008 from Academic Search Premier database.

Hiltz, S. R., \& Turoff, M. (2005). Education goes digital: The evolution of online learning and the revolution in higher education. Communication of the ACM, 48(10), 59-64. Retrieved July 21, 2009 from EBSCOHost database. 
Lamb, A. C. \& Smith, W. L. (2000). Ten facts of life for distance learning courses. TechTrends, 44(1), 1215. Retrieved from http://eric.ed.gov/ERICWebPortal/search/detailmini.jsp? nfpb=true\& \&ERICExtSearch SearchValue 0=EJ613331\&ERICExtSearch_SearchType $0=$ no\&accno=EJ613331

LaPadula, M. (2003). A comprehensive look at online student support services for distance learners. American Journal of Distance Education, 17(2), 119-129. Retrieved March 15, 2009 from Academic Search Premier database.

Levernier, E. L. (2005). An analysis of perceptions of online instruction by department chairs in the field of higher educational administration in the United States. (Ed.D. dissertation, Georgia Southern University, Statesboro, Georgia) Retrieved February 9, 2008 from ProQuest Digital Dissertations database. (AAT 3181000)

Maor, D. (2003). The teacher's role in developing interaction and reflection in an online learning community. Education Media International, 40(1) 127-138. Retrieved July 20, 2008, from EBSCOHost database.

Marra, R. M., Moore, J. L., \& Klimczak, A. D. (2004). Content analysis of online discussion forums: A comparative analysis of protocols. ETR\&D, 52(2), 23-40. Retrieved July 20, 2008 from EBSCOHost database.

Marx, G. (2006). Future-focused leadership: Preparing schools, students, and communities for tomorrow's realities. Alexandria, VA: Association for Supervision and Curriculum Development.

McClure, A. (2007). Distant, not absent. University Business, 10(11), 40-44. Retrieved July 22, 2008 from EBSCOHost database.

Merriam, S. B. (2001). Andragogy and self-directed learning: Pillars of adult learning theory. In S. Merriam (Ed.), New directions for adult and continuing education: The new update on adult learning theory (pp. 3-14). Hoboken, NJ: Wiley.

Merriam, S. B. (2008). Adult learning theory for the twenty-first century. New Directions for Adult \& Continuing Education, 119, 93-98. doi: 10.1002/ace.309

Nelson-Reed, V. C. (2006). Distance education and the financial aid process: A college student's perspective. (Ph.D. dissertation, Capella University, Minneapolis, Minnesota) Retrieved March 18, 2008 from ProQuest Digital Dissertations database. (AAT3239149)

Nichols, M. (2010). Student perceptions of support services and the influence of targeted interventions on retention in distance education. Distance Education, 31(1), 93-113.Retrieved June 12, 2010 from EBSCOHost database.

Noblit, G. W., \& Hare, R. D. (1988). Meta-ethnography: Synthesizing qualitative studies. Newbury Park, CA: Sage Publications.

Oliver, M., \& Conole, G. (2003). Evidence-based practice and e-learning in higher education: Can we and should we? Research Papers in Education, 18(4), 385-397. Retrieved July 25, 2008 from EBSCOHost database.

Palloff, R. M., \& Pratt, K. (1999). Building learning communities in cyberspace: Effective strategies for the online classroom. San Francisco: Jossey-Bass.

Palloff, R. M., \& Pratt, K. (2003). The virtual student: A profile and guide to working with online learners. San Francisco: Wiley.

Parsad, B., \& Lewis, L. (2008). Distance education at degree-granting postsecondary institutions: 200607. National Center for Education Statistics, Institute of Education Sciences, U.S. Department of Education. Washington, D.C. Retrieved from http://nces.ed.gov/pubs2009/2009044.pdf

Paul, R., \& Elder, L. (1996). Universal intellectual standards. Retrieved July 27, 2008 from http://www.criticalthinking.org 
A Meta-ethnographic Synthesis of Support Services in Distance Learning Programs

Proserpio L., \& Gioia, D. A. (2007). Teaching the virtual generation. The Academy of Management Learning and Education, 6(1), 69-80. Retrieved July 21, 2008 from EBSCOHost database.

Rovai, A. P., Ponton, M. K., \& Baker, J. D. (2008). Distance learning in higher education: A programmatic approach to planning, design, instruction, evaluation, and accreditation. New York: Teachers College Press.

Ruth, D. (2005). An investigation into the need for co-curricular student services for distance education students. (Ph.D. dissertation, Drexel University, Philadelphia, Pennsylvania) Retrieved March 18, 2008 from ProQuest Digital Dissertations database. (AAT3167553)

Schauer-Crabb, C. A. (2002). A case study of adoption and diffusion of an existing asynchronous distance learning program. (Ph.D. dissertation, Virginia Polytechnic Institute and State University, Blacksburg, Virginia) Retrieved March 18, 2008 from ProQuest Digital Dissertations database. (AAT3106792)

Seidel, J. V. (1998). Qualitative data analysis. Retrieved April 1, 2009 from http://www.qualisresearch.com/DownLoads/qda.pdf

Seidel, J. V. (2008). The Ethnograph 6.0 User's Guide [Computer software]. Colorado Springs, Colorado: Qualis Research.

Sims, R. (2008). Rethinking (e)learning: A manifesto for connected generations. Distance Education, 29(153-164). Retrieved July 28, 2008 from Academic Search Premier database.

Tambi, Ghazali, \& Yahya. (2008). The ranking of higher education institutions: A deduction or delusion? Total Quality Management, 19(10). doi: 10.1080/14783360802264046

Telig, R. W., Lundy, L., Irani, T., Bielema, C., Dooley, K. E., Anderson, E., \& Raulerson, R. (2005). Distance education training for distance education trainers: The roadmap to effective distance education design project. The Quarterly Review of Distance Education, 6(1), 331-342. Retrieved July 23, 2008 from EBSCOHost database.

Tuquero, J. M. (2010). A meta-ethnographic synthesis of support services for adult learners in distance learning programs. (Ph.D. dissertation, Capella University, Minneapolis, Minnesota) Retrieved June 6, 2011, from ProQuest Digital Dissertations database. (AAT 3422764).

Ullyatt, D. J. (2003). Satisfaction of students and administrators toward support systems in online degree programs: A case study. (Ed.D. dissertation, Seton Hall University, New Jersey, New York) Retrieved February 9, 2008, from ProQuest Digital Dissertations database. (AAT 3081033)

Vai, M., \& Sosulski, K. (2011). Essentials of online course design: A standards-based guide. New York: Routledge.

Waits, T., \& Lewis, L. (2003). Distance education at degree-granting postsecondary institutions: 20002001. U.S. Department of Education, National Center for Education Statistics. Washington, DC. Retrieved from http://nces.ed.gov/pubs2003/2003017.pdf

Weed, M. (2008). A potential method for the interpretive synthesis of qualitative research: Issues in the development of 'meta-interpretation'. International Journal of Social Research Methodology, 11(1), 13-28. Retrieved March 28, 2009. doi:10.1080/13645570701401222

Western Cooperative for Educational Telecommunication. (2002). Beyond the administrative core: Creating internet-based student services for online learners. Retrieved March 7, 2009 from http://wcet.info/services/studentservices/beyond/index.asp

Zemke, R. (2002). A pocket guide to useful learning theories. Training, 39(9), 90-92. Retrieved February 5, 2009 from EBSCOHost database.

Zieger, L.B. (2005). The relationship between student orientation programs that support community building and retention of distance learners. (Ed.D. dissertation, Pepperdine University, Malibu, California) Retrieved March 19, 2008, from ProQuest Digital Dissertations database. (AAT 3191663) 


\section{Biography}

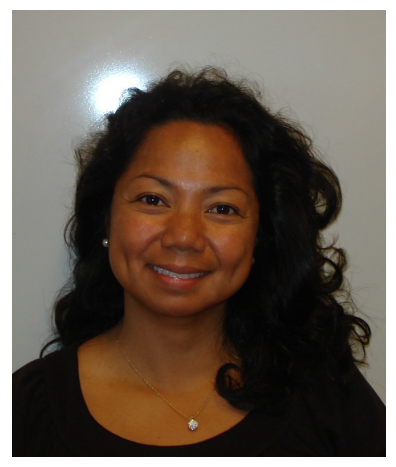

Jean Marie Tuquero is an elementary school teacher with the US Department of Defense Education Activity, Guam District. She has seventeen years experience and hold certifications as a school educational technologist and teacher for grades 1-8. She earned her Bachelors Degree in Elementary Education from the University of Guam in 1992. Her desire to extend and enrich her teaching led to a MA in Curriculum and Instruction in Computer Education from the University of Phoenix in 2005 and a Ph.D. in Postsecondary and Adult Education from Capella University in 2010. She is a teacher leader who helps her colleagues at Commander William C. McCool Elementary/Middle School integrate cutting edge instructional technologies into daily instruction.

She is deeply engaged in developing strategies to use technology to impact student achievement through improved instructional practices. Her current interests include the development of ecological literacy and STEM curriculum focusing on elementary and middle grades and the integration of job embedded professional development of in-service teachers to improve classroom teaching and learning. 